\title{
Theologia and the Ideologica of Language: The calling of a theology and religion faculty in a time of populism
}

\begin{tabular}{|c|c|}
\hline \multicolumn{2}{|c|}{$\begin{array}{l}\text { Author: } \\
\text { Johann-Albrecht Meylahn }{ }^{1} \text { (D) }\end{array}$} \\
\hline \multicolumn{2}{|c|}{$\begin{array}{l}\text { Affiliation: } \\
{ }^{1} \text { Department Practical } \\
\text { Theology, Faculty of } \\
\text { Theology, University of } \\
\text { Pretoria, South Africa }\end{array}$} \\
\hline $\begin{array}{l}\text { Research Proje } \\
\text { Project Leade } \\
\text { Project Numb }\end{array}$ & $\begin{array}{l}\text { ect Registration: } \\
\text { r: J.A. Meylahn } \\
\text { er: } 02187133\end{array}$ \\
\hline \multicolumn{2}{|c|}{$\begin{array}{l}\text { Description: } \\
\text { This research is part of the } \\
\text { project, 'Towards a practical } \\
\text { postfoundational theology as } \\
\text { public theology in response } \\
\text { to the challenges of lived } \\
\text { religion in contemporary } \\
\text { Southern Africa', directed by } \\
\text { Prof. Dr Johann Meylahn, } \\
\text { Department Practical } \\
\text { Theology, Faculty of } \\
\text { Theology, University of } \\
\text { Pretoria. }\end{array}$} \\
\hline \multicolumn{2}{|c|}{$\begin{array}{l}\text { Corresponding author: } \\
\text { Johann-Albrecht Meylahn, } \\
\text { johann.meylahn@up.ac.za }\end{array}$} \\
\hline \multicolumn{2}{|c|}{$\begin{array}{l}\text { Dates: } \\
\text { Received: } 26 \text { June } 2017 \\
\text { Accepted: } 07 \text { July } 2017 \\
\text { Published: } 22 \text { Aug. } 2017\end{array}$} \\
\hline \multicolumn{2}{|c|}{$\begin{array}{l}\text { How to cite this article: } \\
\text { Meylahn, J-A., 2017, } \\
\text { 'Theologia and the Ideologica } \\
\text { of Language: The calling of a } \\
\text { theology and religion faculty } \\
\text { in a time of populism', HTS } \\
\text { Teologiese Studies/ } \\
\text { Theological Studies 73(4), } \\
\text { a4717. https://doi. } \\
\text { org/10.4102/hts.v73i4.4717 }\end{array}$} \\
\hline \multicolumn{2}{|c|}{$\begin{array}{l}\text { Copyright: } \\
\text { (C) 2017. The Authors } \\
\text { Licensee: AOSIS. This } \\
\text { is licensed under the } \\
\text { Creative Commons } \\
\text { Attribution License. }\end{array}$} \\
\hline \multicolumn{2}{|l|}{ Read online: } \\
\hline ㅁiptra & $\begin{array}{l}\text { Scan this QR } \\
\text { code with your } \\
\text { smart phone or } \\
\text { mobile device } \\
\text { to read online. }\end{array}$ \\
\hline
\end{tabular}

This article represents a response to Andries van Aarde's view on a 'gateway to the future from a deconstructed past', a paper presented as part of a conference, 'Gateway to the Future from a Deconstructed Past', commemorating the centennial anniversary of the Faculty of Theology at the University of Pretoria, 05-06 April 2017. The article argues that texts, and theology faculties as texts, are just as any structure or construction haunted by their sacred secret. Haunted by the ghosts in the texts from the past to be inspired for the calling of a theology and religion faculty in a time of populism and the 'renaissance of (neo)nationalism', according to Van Aarde. In being given the responsibility not only of responding to his contribution but also co-sharing the responsibility of the history of the faculty, the author says that he has a choice: he could respond to the letter of the text or I could be spooked by the ghosts of these texts, the haunting of the sacred secret, calling through Professor Van Aarde's deconstruction of these texts. The author decides to seek to allow the ghosts of his text to call him. A call, as most calls, to which one can only respond: Here I am! Here I am in this moment (here) of history at this particular Faculty of Theology and Religion. This is a call to share the responsibility, the responsibility of being here and the responsibility of the being of a theology and religion faculty in a time of populism and (neo)nationalism, both globally and locally.

\section{In response}

I was asked to respond to the article by Professor Andries van Aarde, Theologia and the Ideologica of Language, Nation, Gender, and the Circle of International Footprints. Yet to respond is to take responsibility, but to take or to be given responsibility for what? What does it mean to be given or to take responsibility to respond? To respond to a paper, which is a paper responding or taking the responsibility for the history of a theology faculty in the year in which this faculty is celebrating 100 years, one is responding to a response, or taking (being given) responsibility for the responsibility of 100 years of history as well as opening the gates to the future. Jan Patočka, the Czech philosopher, relates secrecy or the mystery of the sacred to responsibility (Derrida 2008:3). In that sense, to take or to be given responsibility is to take or be given responsibility for the secret. Such taking responsibility for the secret is for Patočka the birth of religion, and yet in this birth, there is also the temptation of ideology or the temptations of ethics in Kierkegaard's sense. The Faculty of Theology of the University of Pretoria, celebrating its centenary, has decided to take responsibility for the past, or history has given it this responsibility: the responsibility for the sacred secret of a theology faculty. To take this responsibility, to be given this responsibility, is the birth of religion and therefore it is very fitting that our faculty this centenary year has decided to take on a new name in the future: Faculty of Theology and Religion.

In his article, Andries van Aarde returned to the texts of some of the founding fathers of this faculty to hear their call, to hear the ghosts of their texts, the Spirit of these texts, but hearing their call in the present with a view towards the future.

Texts, and theology faculties as texts, are just as any structure or construction haunted by their sacred secret. Haunted by the ghosts in the texts from the past to be inspired for the calling of a theology and religion faculty in a time of populism and the 'renaissance of (neo)nationalism' (Van Aarde 2017:1). In being given the responsibility not only of responding to his paper but co-sharing the responsibility of the history of the faculty, I have a choice: I could respond to the letter of the text or I could be spooked by the ghosts of these texts, the haunting of the sacred secret, calling through Professor Van Aarde's deconstruction of these texts. His deconstruction of these texts through a contextual reading, where he takes both the historical and today's context into consideration, is taking up the responsibility for the faculty's history and thereby opening the gates to a future. 
I will seek to allow the ghosts of his text to call me. A call, as most calls, to which one can only respond: Here I am! Here I am in this moment (here) of history at this particular Faculty of Theology and Religion. This is a call to share the responsibility, the responsibility of being here and the responsibility of the being of a theology and religion faculty in a time of populism and (neo)nationalism, both globally and locally. Populism and (neo)nationalism was a threat that Professor Van Aarde identified, and the fathers to whom he alluded offered insights as to a possible response to nationalist and populist times.

Professor Van Aarde focussed on what one can learn from these texts, by identifying crucial lessons. He focussed specifically on gender inclusion. He did this by facing the past, with the questions of the present so as to hear the calling of the future. I would like to respond by seeking to hear the calling of the future in the ghosts of the past, which in deconstruction always opens closed gates - opens the enclosure.

\section{Being a theology and religion faculty in a time of populism}

Professor Van Aarde acknowledges that there are different views concerning populism (Van Aarde 2017:11), where it also does not matter if it is defined as a 'thin-centred ideology' or a full-ideology (Van Aarde 2017:11), or as 'rhetoric that voices the "the will of the people" over against that of the "corrupt elite"' (Van Aarde 2017:11).

Populism, as the voice of the people against the corrupt elite, sounds democratic, as it seems to want to respond to the needs of those, whose voices do not have, or no longer have a platform to speak or to be heard: the voices of the poor, or the working class or the 'forgotten' middle class. The call to hear unheard voices, or oppressed, or silenced voices is indeed a central democratic ideal, namely: the creation of free and egalitarian spaces for equal and free communication.

My concern is the platform that is created for these voices to speak. In this article I will follow Ernesto Laclau's view of populism, as 'a way of constructing the political' (Laclau 2007:xi).

In the ancient Greek understanding of justice, dike , justice was understood as giving space, room, or voice to those who had no voice or space (see Heidegger 1971a:357, 368). But, as Heidegger argues, nothing is unconcealed, receives voice or is given a platform, without concealment (see Heidegger 1971b:38). Voices are heard, things (people, animate and inanimate things) are given space within an onto-logy, within a world with its particular onto-logy, yet it is the world $(\log y)$ that gives space and identity that is concealed, or not recognised, as it is taken for granted. The world or the platform, in which the voice-less voices are heard or given voice by being included in the ontology of that platform, is the logos of that ontology. The logos that bind (religare) that particular world (ontology) is concealed or is not thought, as it is perceived as given or natural (the way things are).
It is on this platform, this world, which is concealed, that I would like to focus, as this concealed platform or world or logos of the ontology is constructed, as Charl Schmitt (see Derrida 2005:67) argues a city (polis) is constructed through the creation of a clear enemy. Any ontology is created by a clear logos that classifies, defines, includes and excludes, as it binds together all the onta into an ontology. All the things of that ontology are identified, classified and defined by being given a clearly identified space and indeed a place within a certain hierarchy. In the case of populism, as already mentioned, the clearly defined enemy is the 'corrupt elite', and thus your place in a clearly demarcated 'populous' is determined by your politically correct view and attitude towards the clearly defined enemy. Or as Ernesto Laclau argues, three conditions need to be met for the rise in populism:

1. the formation of an internal antagonistic frontier separating the 'people' from power;

2. an equivalential articulation of demands making the emergence of the 'people' possible.

3. There is a third precondition which does not really arise until the political mobilisation has reached a higher level: the unification of these various demands - whose equivalence, up to that point, had not gone beyond a feeling of vague solidarity - into a stable system of signification (Laclau 2007:74).

This world, the 'true people', with their clearly identified enemy, present themselves as the solution to all societal problems. In its attempt to unite the people it reduces phenomena to singular truths (stable system of signification), such as migration, white capital, white privilege, black pain, land, colonialism, decolonialism, liberalism, free market, democracy, etc.

One could argue that the Brexit vote in the United Kingdom was a populist vote, the election of President Trump was a populist victory and the political gains of Geert Wilders in the Netherlands, Marine Le Pen in France and Frauke Petry in Germany are signs of the rise of populism as well as (neo)nationalism. South Africa has its own populist movements that reduce all societal problems to singular evils, or reduce all solutions to singular answers on both sides of the racial and economic divide. Is all politics not populist in a sense, where in the end, you have two or more populist worlds facing each other? A world where white capital is the clear enemy and another world where 'free' market-economy and constitutional democracy as 'only' answer? The reduction to singular answers and singular evils is not new, and maybe it has and will remain a temptation for humanity, or an unavoidable ingredient in the construction of the political. The knowledge of truth, as the knowledge of what is good (salvation) and what is evil (damnation or the root cause of all problems) is as ancient as humanity itself, at least according to the book of Genesis, with the tale of the fall of humanity, by eating of the fruit of the tree of knowledge of good and evil.

Professor Van Aarde reflected on the two words: Theology and Ideology, which are linked to this knowledge, the knowledge of 
the good, knowledge of God, and consequently knowledge of evil, the bad and the enemy, which seems to be constitutive of any polis, any community, any ontology. It is the binding (religare) of a group of people into a community, binding people into a political identity, via an idea (that which is one's own) of the good (God), the logos of any onto-logy (see Badiou 2009:39). Patočka, like Kierkegaard, has a different view of religion and does not interpret religion as the binding force, but as a radical and even absolute liberation from such binding, because for him it is absolute (radical) responsibility. For Patočka, as for Kierkegaard, the religious responsibility (unconditional responding to the Other) would be interpreted as irresponsibility in the world (Derrida 2008:62). Religion as religare, as the binding force, Potačka would see as being part of the orgiastic or demonic mystery cults (see Derrida 2008:4-5) from which only religion can liberate.

Van Aarde (2017:3) refers to ideology as being rooted in words such as idea [what is own] and eidolon [divine image]. The divine image of God or of the good that binds the community into a polis, including all those who believe to have the truth, the answer, the good, whilst excluding all those who do not have the same truth, good or answer and interpreting them as the enemy. How does one critique ideology and in a certain sense also theology: the logos of ideas that bind (religare), the logos of the good that binds into a polis, the logos of God that binds into a systematic theology, a doctrine and a denomination?

Ernesto Laclau (2014:13-15) reflects on the question of ideological critique. How would one critique a particular community's (polis) view of what is their own, their particular ideas, and/or their view of their divine or their good [God]? Such a critique would either be another ideology of religion, with the result that one would be critiquing one ideology or religion with another. To get beyond critiquing ideology with ideology one would need to argue that there is an extraideological position from which to critique ideology as such. If there is such an extra-ideological position, one could argue that all ideology is a distortion, and/or a false consciousness, from which people need to be liberated. Yet, such radical critique of ideology could only be based on the belief that one has access to the extra-linguistic, for example, access to the Real of reality, which has often been believed, for example, in various forms of materialism, which understood themselves as critiques of idealism and therefore critique of ideology. Laclau argues, 'any notion of an extra-discursive viewpoint is the ideological illusion par excellence' (2014:13). Ideological illusion par excellence is the belief that one hears the cry of the Real world. The belief that the world, the platform, where voices of the previously voiceless are heard, is taken to be the Real world: the Real material conditions.

The cry of the voiceless, the cry of the displaced or placeless is indeed a call for justice, but it is simultaneously the danger for ideological distortion. Between hearing the cry of the people in the land of slavery and knowing what the real conditions are, as well as knowing the best route to the promised land, stands the tree of knowledge of good and evil.
One cannot in the current political and economic time abandon any form of ideological critique, as the time calls for responsible ideological critique.

Yet, all ideologies are equally valid or not valid as there is no extra ideology, outside ideology or extra linguistic access to reality. If all ideologies are equally valid or invalid, one would have to accept current populist movements, as ideological distortions, but no more or no less than mainstream centre left or centre right politics, which are equally ideologically distorted. Distortion can no longer serve as a critique of ideology but is constitutive of ideology (see Laclau 2014:16). An ideological distortion is where a particular view of reality is taken to be the real or actual view of the Real. When something (an idea) is taken to be the real or natural world is how Geertz (1993:90) and Berger ${ }^{1}$ understand the role of religion. The religious element in the social construction of reality is when a construction is believed to be the real, is believed to be nature or the real world as God created it, or the real world as science proved or discovered it.

The secret, the sacred secret, the Real or Truth, is always distorted, or shrouded in mystery and never fully revealed, as there is nothing outside the text (see Derrida 1997:158), there is nothing outside of ideology or religion.

This is the double bind that human beings find themselves in. Humans are the creatures who construct meaning and thereby construct the worlds in which they live. Humans live in culture as opposed to nature, and eventually believe that their culture is nature. It is what makes humans, humans and therefore this closure of meaning (the creation of a world the carrying out of a world through the silent speaking of language) is necessary and unavoidable, even if the closure, the final meaning, is impossible. ${ }^{2}$ If this carried out world was perfect there would not be any problems, but because it is imperfect, for example in that it excludes, the excluded knock on the door or boundaries of these worlds, cracking and challenging the boundaries of these worlds seeking hospitality.

The ideological effect is the belief that there is a 'particular social arrangement that can bring about the closure and transparency of the community' (Laclau 2014:17), as well as the belief that there is one particular medicine (pharmakon) that can heal these cracks or transform this closure into a perfect closure (inside). Although this is a radical critique of ideology and/or religion, what needs to be remembered is that this illusion is a necessary one, therefore ideology or

1.Finally, there are highly theoretical constructions by which the nomos of a society is legitimated in toto in which all less-than-total legitimations are theoretically integrated in an all-embracing Weltanschauung ...

This last level may be described by saying that here the nomos of society attains theoretical self-consciousness ..

Religion legitimates social institutions by bestowing upon them an ultimately valid ontological status, that is, by locating them within a sacred and cosmic frame of reference from a vantage point that, in its own self-definition, transcends both history and man (Berger 1967:32-34).

2.'the operation of closure is impossible but at the same time necessary - impossible because of the constitutive dislocation lying at the heart of any structural arrangement; necessary because, without that fictitious fixing of meaning, there would not be meaning at all' (Laclau 2014:16) 
religion is a necessary element and can therefore not be suppressed or excluded. 'There is ideology whenever a particular content shows itself as more than itself' (Laclau 2014:17), which is humanity's only access to meaning, namely, via metaphor - a part for the whole.

For example, it is often believed that a return to moral values could be the panacea for all the social-economic-political ills facing South Africa. Onto moral values is projected the closure and fullness (kingdom of heaven) of a good, perfect and just society. In other words, according to Laclau's arguments, moral values would incarnate the fullness of society. Yet, in this incarnation, moral values are deformed into much more than just the 'right way to live', but become the incarnation of emancipation from corruption and the alleviation from poverty, in short: 'the possibility of constituting the community as a coherent whole' (Laclau 2014:17).

Ideology projects onto a particular object, for example, moral values, white capital, migration, land redistribution, heterosexual marriage, family values or the dream of the fullness of a particular community or class.

Closure is impossible, and as being impossible cannot have content on its own but needs to project its 'content' onto an object different from itself. This object will assume the role of incarnating the closure of an ideological horizon but will in the process of incarnating the closure be deformed (see Laclau 2014:17). It is deformed by what Laclau (2014:18) calls equivalence, which is not identity. In other words, there are always other words or terms which can replace each other, and more importantly, which can be enumerated, and thereby become floating signifiers, to give meaning to the empty signifier (Laclau 2014:20): the absence of fullness. Democracy or justice is such empty signifier and is loaded with floating signifiers that can be enumerated to indicate the direction of the empty signifier. At times, a singular floating signifier is chosen as the Signifier and not as empty signifier but as full signifier. Onto this particular signifier is incarnated the full meaning of the empty signifier and thereby it is distorted, and that is for Laclau the dual working of ideology. These two moments or movements are mutually dependent and as such form the two movements of ideological dialectic: incarnation and deformation.

\section{By doing theology and religion}

Theo-logos can be interpreted as the word from God or the word of God or the word about God or the science of God or knowledge about God. There are numerous theological traditions, words of God, each with their particular focus. I would like to focus only on two very broad traditions: negative theology and positive theology. The particular interest is with negative theology with its mystical tradition, which, according to Stace (1960:61f.), can be divided into extrovertive and introvertive mysticism. One can either offer numerous positive characteristics of God, and enumerate them, listing them, each as a floating signifier, which together indicate something of the ineffable God, an empty signifier, or, as Scholem argues for the difference between allegory and symbol. Allegory could be seen as floating signifiers, who together create the symbol. ${ }^{3}$ The danger is if one of these floating signifiers, or one of the allegories is taken as the symbol or is taken as the full signifier as in some positive theological traditions. Or the mysticism of Meister Eckhart, for example, where the limits of language are clearly reached and where one needs to distort language to express that which is beyond expression. 'This is a generalized tendency within mysticism: a distortion of language that deprives it of all representative function is the way to point to something beyond all representation' (Laclau 2014:39). The danger is when language is not distorted but is taken to be clear and univocal, it is taken to be positive.

This mystical experience is true of all experience as the wholly Other of mysticism is every other. Thus, the trouble with theology, or theology's concern of how to speak of the Other, is the concern of humanity as such: how to speak and consequently how to think; how to speak of the Other, who is every other (Derrida 2008:78-79). This question of speaking is a question of responding, taking or being given responsibility. How to respond to the other? Into what responsibility is humanity thrown? What responsibility is the gift bestowed on humanity?

Derrida argues that Abraham's experience, the Akedah, is the experience of humanity ${ }^{4}$ as such, as it is the experience of being human and the experience of the everyday. The everyday responsibility is what humanity is thrown into. The question is, does humanity take up this responsibility? It seems theology is the science of this responsibility, as it has provided the stories, the fictions for this responsibility, which indeed would make theology the queen of the sciences as it tells the story of this responsibility.

It is interesting that the story of Abraham and the Akedah on Mount Moriah, has called into responsibility three religions. Mount Moriah is believed to be the place where Salomon built the Temple, the place where today stands the mosque, the Dome of the Rock, and just behind the mosque, is the Via Dolorosa, the way of the cross. Three religions responding to this call, taking responsibility for this call of Abraham, the father of faith, or the knight of faith as Kierkegaard called him. Three different responses and each by responding religion is born. Yet, in these three responses, the responses include only the father and son, and the mother, Sarah, is excluded. The mother, the woman is excluded, which seems to be true of these three religions, as these theologies have for centuries and even still today excluded women. And yet, ironically, it was Sarah, who laughed at the thought that a promise of

3.If allegory can be defined as the representation of an expressible something by another expressible something, the mystical symbol is an expressible representation of something which lies beyond the sphere of expression and communication something which comes from a sphere whose face is, as it were, turned inward and away from us ... The symbol 'signifies' nothing and communicates nothing but away from us ... The symbol "signifies" nothing and communicates nothing but makes something transparent which is beyond all expression. Where deeper insight into the structure of the allegory uncovers fresh layers of meaning, the symbol is intuitively understood all at once - or not at all... It is a 'momentary totality' which is perceived intuitively in a mystical now - the dimension of time proper to the symbol (Scholem 1995:27).

4.Translated into this extraordinary story, the truth is shown to possess the very structure of everyday (Derrida 2008:78). 
fullness could be incarnated, the promised land and nation could be incarnated, materialised in a son beyond the childbearing possibilities according to 'laws of biology'. Humour, to laugh at paradox is, as Bergson reminds us, a creative response to enigma, contradiction and paradox (Kearney 2010:42). Or as Hegel once argued, that women are the eternal irony of the community (Derrida 2008:77). Sarah laughed at the idea, she laughed at the idea that the good, the promise, could be incarnated in the particular. She laughed and knew the impossibility thereof, perhaps also recognising the necessity thereof for her husband. If only theology had listened to her laugh, yet theology has used her laugh to further discriminate against her, and continue to exclude women, often arguing that she has no sense for theology.

Taking or being given responsibility is the birth of religion for both Potačka and Kierkegaard (see Derrida 2008:54-81). How fitting is that the three religions of the book should gather in response in such close proximity to the Akedah.

\section{The calling of a Theology and Religion Faculty: Se donner la mort - To give oneself death, as the gift of History with a future}

The call and the response, taking or being given the responsibility, is the birth of religion and the birth of history. Abram living comfortably with his family in their culture is one day called, addressed, and he responds, as so often, with the only words with which to respond to such a call: here I am. A call that calls one into Dasein - to be here, in other words, to be there where one responds to the call. Who is it that calls? Where does one hear that call? Is it a voice from the heavens, or the crying of the earth, the Real? The voice is maybe only heard in the tremors of the heart. It is the voice of the wholly Other, who is every other, the mysterium tremendum, the mysterious tremors of the heart, the voice of the other, which one hears in giving it to oneself. As Heidegger argues, 'Der Ruf kommt aus mir und doch über mich' (See Derrida 2008:34). The $m e$ responding gives a name to the caller by and through responding, and in naming the caller the me becomes an $I$, the I of Here I am (Dasein). In naming, poiesis, the addressed me becomes a subject, a Dasein in her or his response. A response, a responsibility that she or he has given to her or himself by giving voice to the Other - the call that she or he heard.

Abram, a subject, a Dasein, in a particular culture, in a particular world, hears a call. He responds and the journey begins, faith begins, religion begins with the taking, or the being given this responsibility. Was it the call of the Real, was it the call of God, was it the call of the Other, who is every other (see Derrida 2008:82ff.)? Abram left the ideology, hearing the call of the other of ideology: the Real perhaps? Theologians have taken this story, written this story and made it a founding story of theology and thus the beginning of literature. Theology-Religion as the responsibility of responding.
Abram responding becomes Abraham, the father of faith, his response, his responsibility is rewarded with a promise: land and offspring - the promised land and the promised nation.

Abraham, after many years of responding, and failing in his responsibility, eventually receives a son, from his wife Sarah: Isaac. Isaac, an incarnation of the promise, the fulfilment of the promise. In Laclau's sense, Isaac is both incarnation and deformation, as Isaac becomes much more than just a son, he becomes the materialisation of a promise, he becomes the actualisation of the hoped for - Isaac becomes ideology or Theology. The name Isaac means he laughs; is it the laughter of joy, the laughter of our relationship with the ungraspable Other, a divine comedy, or is it the laughter of irony? Kearney argues that humour 'in this special sense, is deep humility before the excess of meaning the divine stranger carries like a halo round his head' (Kearney 2010:43).

The call is there again, to which Abraham responds, Here I $a m$, but this time he is asked to sacrifice the incarnation of the promise, to sacrifice the actualisation of the hoped-for, in response, in responsibility, to none other than the call. A call that he hears nowhere else than in the tremor of his heart. Abraham, in responsibility to this call, defies the ethic of his culture, defies the ethic of his ideology, defies his theology which has bound him to his wife, namely his son and the journey to the promised land. He is asked to sacrifice his son and with the son, the promise of the promised land, which has become the ideology of the promise, the theology of the promise, and therefore he cannot but keep it secret. Abraham tells no one what he has to do as he alone is responsible in the singularity of the Here I am.

That he has to give the gift of death, death to the materialisation, death to the incarnation-deformation of the promise, but give this gift of death to whom? To whom does he give this gift of death? To God or to himself?

Religion or theology, the gift of death, which is a gift given to ourselves, to history, to the university, to politics, so that the gates of history and this faculty remain open.

'Pardon for not meaning (to say) ...' (see Derrida 2008:143f.). It is with this gift of death that we ask and receive forgiveness from ourselves, for what we did not mean to say.

\section{Acknowledgements Competing interests}

The author declares that he has no financial or personal relationships which may have inappropriately influenced him in writing this article.

\section{References}

Badiou, A., 2009, Logics of worlds: Being and event, 2, transl. A. Toscano, Continuum, London.

Berger, P., 1967, The sacred canopy: Elements of a sociological theory of religion, Anchor Books, New York.

Derrida, J., 1997, Of grammatology, transl. G.C. Spivak, John Hopkins Press, Baltimore, $\mathrm{MD}$. 
Derrida, J., 2005, The politics of friendship, transl. G. Collins, Verso, London.

Derrida, J., 2008, The gift of death and Literature in secret, 2 nd edn., transl. D. Wills, University of Chicago Press, Chicago, IL.

Geertz, C., 1993, 'Religion as a cultural system', in The interpretation of cultures: Selected essays, Geertz, Clifford, pp. 87-125, Fontana Press, London.

Heidegger, M., 1971a, Gesamtausgabe, B 29/30 Holzwege, Frankfurt, Klostermann.

Heidegger, M., 1971b, On the way to language, transl. P. Hertz, Harper \& Row, New York. Kearney, R., 2010, Anatheism: Returning to God after God, Columbia University Press, New York.
Laclau, E., 2007, On populist reason, Verso, London.

Laclau, E., 2014, The Rhetorical Foundations of Society, Verso, London.

Scholem, G., 1995, Main trends in Jewish Mysticism, Schocken, New York. Stace, W.T., 1960, Mysticism and philosophy, J. B Lippincott, Philadelphia, PA.

Van Aarde, A., 2017, 'Theologia and the Ideologica of Language, Nation, Gender, and the Circle of International Footprints', Paper presented at the Centenary Conference of the Faculty of Theology at the University of Pretoria, Gateway to the Future from a Deconstructed Past, 5-6th April 2017. 